
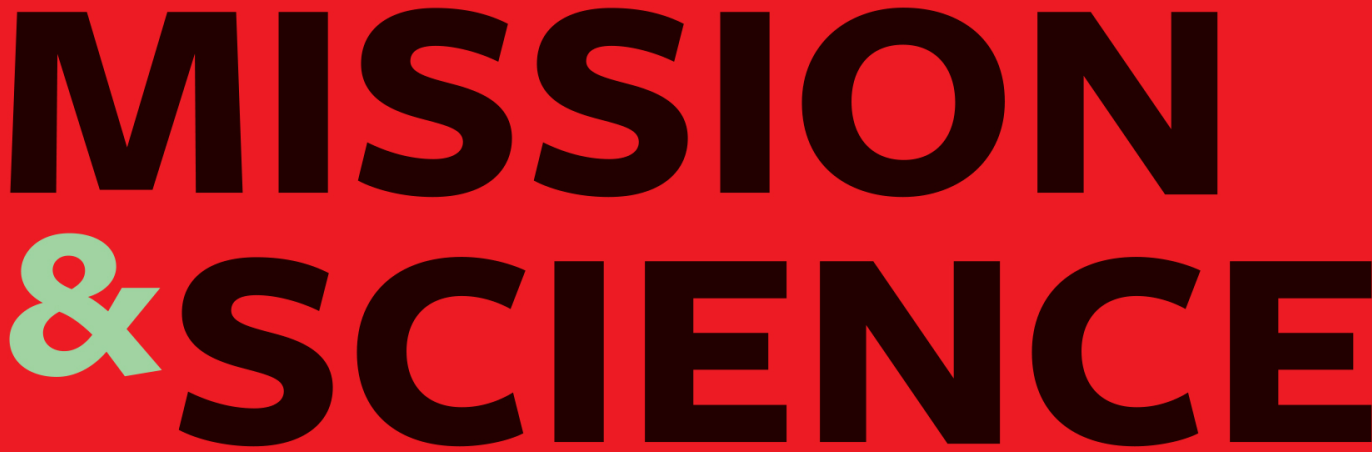

MISSIOLOGY REVISED MISSIOLOGIE REVISITÉE 1850-1940

Carine Dujardin \& Claude Prudhomme, eds

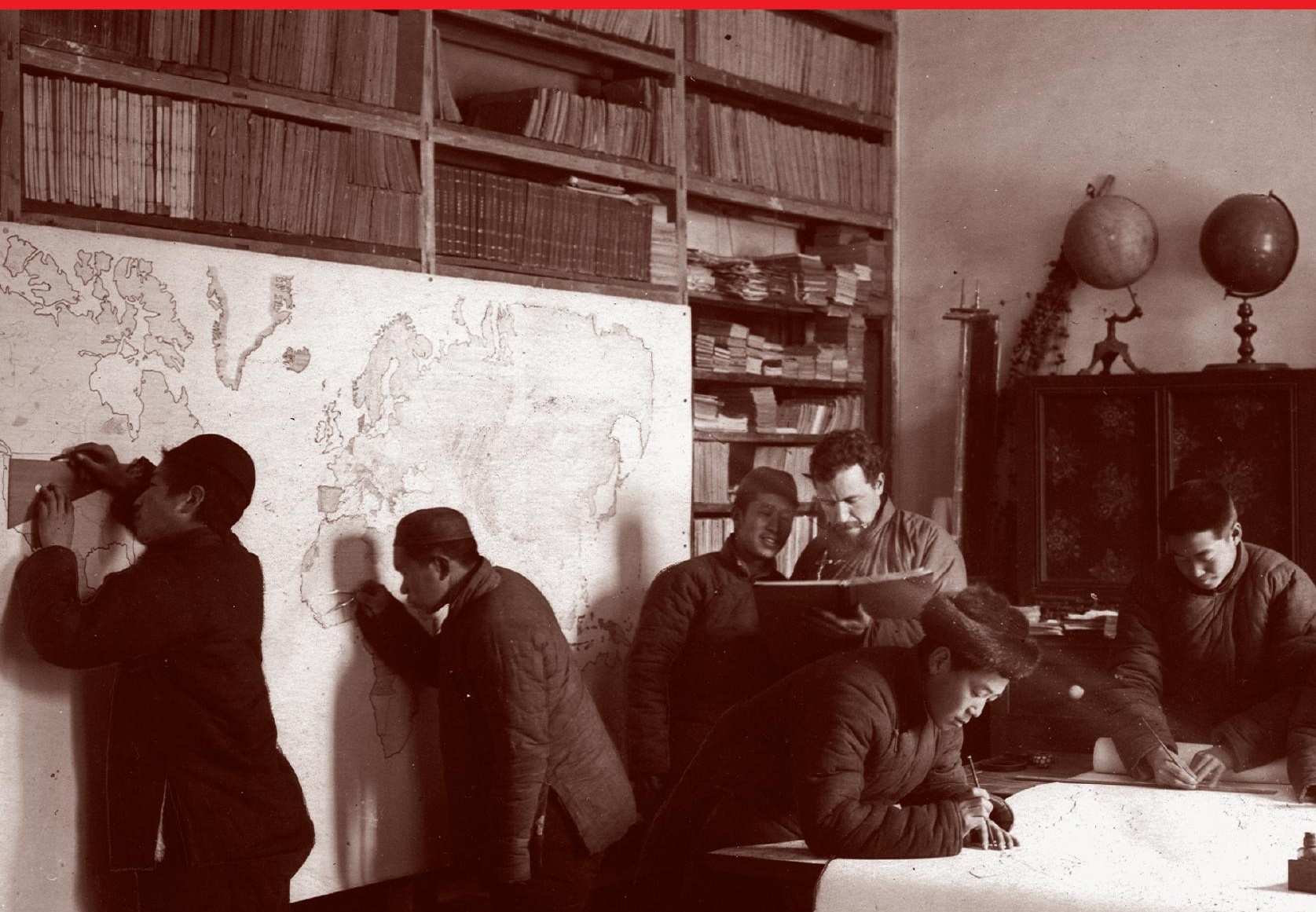


Mission \& Science

Missiology revised/ Missiologie revisitée, 1850-1940

Reprint from Mission \& Science - ISBN 9789462700345 - @ Leuven University Press, 2015 
Reprint from Mission \& Science - ISBN 9789462700345 - @ Leuven University Press, 2015 

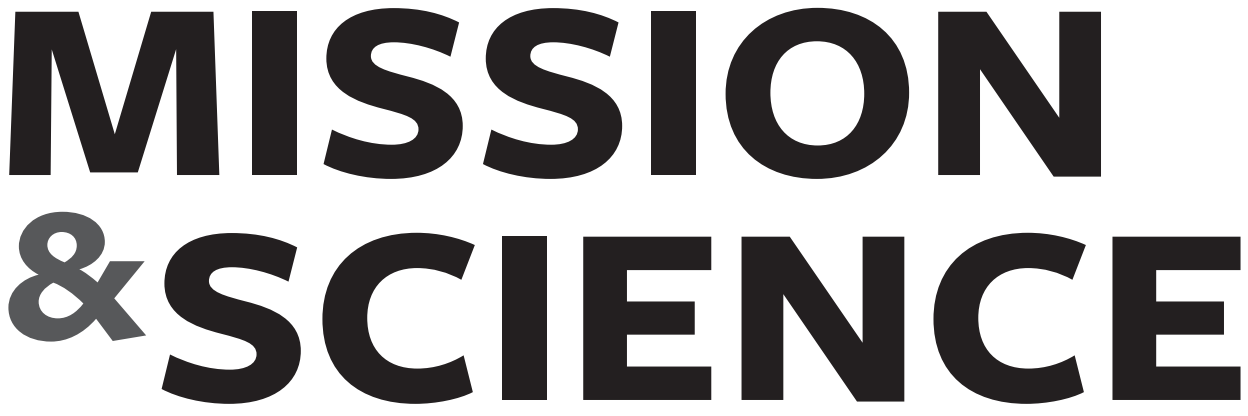

MISSIOLOGY REVISED MISSIOLOGIE REVISITÉE 1850-1940

Carine Dujardin \& Claude Prudhomme, eds 


\section{EDITORIAL BOARD}

Urs Altermatt, Université de Fribourg

Timothy Brittain-Catlin, University of Kent

Wilhelm Damberg, Ruhr-Universität Bochum

Jan De Maeyer, KU Leuven - KADOC

Jean-Dominique Durand, Université Lyon 3

Emmanuel Gerard, KU Leuven - KADOC

James C. Kennedy, Universiteit van Amsterdam

Rupert Klieber, Universität Wien

Mathijs Lamberigts, KU Leuven

Emiel Lamberts, KU Leuven

Jean-Michel Leniaud, École pratique des hautes études, Sorbonne, Paris

Daniele Menozzi, Scuola Normale Superiore di Pisa

Anne Morelli, Université Libre de Bruxelles

Silvia Mostaccio, Université catholique de Louvain

Patrick Pasture, KU Leuven

Liliane Voyé, Université Catholique de Louvain

Cover photo / Photo de couverture: Father Joseph Raskin and seminarians of the Missionaries of Scheut in China, c 1930 / Le père Joseph Raskin et des séminaristes des Missionnaires de Scheut en Chine, vers 1930. [Leuven, KADOC, Archives CICM 17-4-4-4_12]

(C) 2015

Leuven University Press/Presses Universitaires de Louvain/Universitaire Pers Leuven

Minderbroedersstraat 4, B-300o Leuven (Belgium)

All rights reserved. Except in those cases expressly determined by law, no part of this publication may be multiplied, saved in an automated data file or made public in any way whatsoever without the express prior written consent of the publishers.

ISBN 9789462700345

$\mathrm{D} / 2015 / 1869 / 21$

Nur:691, 704

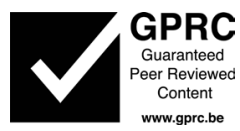




\title{
CONTENTS/TABLE DES MATIÈRES
}

\author{
INTRODUCTION
}

Mission Research Revised

Missiology as a Project of Modernity and a Contemporary Form of Apologetics

Carine Dujardin

La science des missions revisitée

La missiologie comme projet de modernité et forme contemporaine

d'apologétique

Carine Dujardin

I

THE EMERGENCE OF PROTESTANT AND CATHOLIC MISSION STUDY

L'ÉMERGENCE DE LA MISSIOLOGIE PROTESTANTE ET CATHOLIQUE

Protestant Mission Study / La missiologie protestante

The Protestant Mission Study

Emergence and Features

Marc Spindler

La lente émergence de la missiologie protestante comme discipline théologique en France au XIX-XX ${ }^{\mathrm{e}}$ siècle

Jean-François Zorn

Gustaf Lindeberg and the Place of Academic Mission Studies in Sweden,

1910s-1930s

Magnus Lundberg

Protestant Missions and Mission Studies in the Netherlands

Encounter with Roman Catholicism

Jan A.B. Jongeneel

Confronter le monde à la loi de Dieu et à l'Évangile

Johannes Verkuyl et la missiologie protestante aux Pays-Bas

face à la modernité

Jan van Butselaar 
Catholic Mission Study / La missiologie catholique

German Catholic Mission Science

Comments on the Time of its Commencement

Giancarlo Collet

La missiologie en transformation

111

La Zeitschrift für Missionswissenschaft und Religionswissenschaft

et l'Internationales Institut für Missionswissenschaftliche Forschungen

Mariano Delgado \& David Neuhold

Scientia Missionum Ancilla

139

Alphons Mulders and the Beginnings of Mission Studies at Nijmegen University

Peter Nissen

Beyond Pierre Charles

151

The Emergence of Belgian Missiology Refined

An Vandenberghe

Albert Perbal O.M.I. (1884-1971), un missiologue oublié

171

Eugène Lapointe

Sciences pour la mission, sciences de la mission

199

Quel rôle pour la papauté?

Claude Prudhomme

II

MISSIONARIES AND SCIENCE

LES MISSIONNAIRES ET LA SCIENCE

Le musée missionnaire-ethnologique du Latran

De la mission à l'ethnologie, un défi ambitieux

Laurick Zerbini

Doing Science and Teaching Science in Mid-Victorian Missions

of KwaZulu-Natal, South Africa

Norman Etherington

Secular Knowledge and Salvage Anthropology

Henri-Alexandre Junod and the Thonga Tribe

Patrick Harries

'The Sky is the Limit'

271

Missionary Imperatives and Constraints in Determining the Spatial Outline

of the Mongolian Vicariates of the Congregation of Scheut, 1900-1939

Dirk Van Overmeire 
III

285

THEORY VERSUS PRACTICE

THÉORIE VERSUS PRATIQUE

The ‘Three Wise Men' Came from the East

287

Interaction between Missiology and Missionary Practice in Asia, 1890-1940

Carine Dujardin

Protestant and Catholic Missions on Java, Netherlands East-Indies

311

A Comparison of Missionary Thinking, Strategies and Methods

Frans J. Verstraelen

Protestants et catholiques durant la période coloniale et précoloniale au Cameroun dans leur rapport à la science et à la missiologie

Philippe Laburthe-Tolra

Missiology and the Missionary Society of St. Columban

Neil Collins

Protestantism, Catholicism and Islam in German East Africa

Armin Owzar

La mission catholique aux Juifs

371

Un champ missiologique entre études bibliques et attente eschatologique,

ca. 1920-1950

Olivier Rota

\section{CONCLUSION}

Concluding Remarks

381

Towards a Missionary Science?

Claude Prudhomme

Considérations réflexives

Vers une science de la mission?

Claude Prudhomme

Abbreviations / Abréviations

Bibliography / Bibliographie

Index

Authors / Auteurs

Colophon 


\title{
GUSTAF LINDEBERG AND THE PLACE OF ACADEMIC MISSION STUDIES IN SWEDEN, 1910S-1930S
}

\author{
MAGNUS LUNDBERG
}

\begin{abstract}
A cademic interest in missions increased in many parts of the world following the 1910 Edinburgh World Missionary Conference. Scandinavia and Sweden were no exceptions. At that time, there were only two major universities in Sweden: Lund and Uppsala. Both universities had their own theological faculty and to some extent they formed two separate worlds without much cross-fertilization. In this article, I will focus on the place and role of academic mission studies at Lund University in the early decades of the twentieth century, which was more or less equivalent to the work of Gustaf Lindeberg (1878-1961). He will thus be at the centre of our attention.

In 1918, Lindeberg became the first Swede to defend a doctoral dissertation on a purely missiological subject. After completing his doctorate, he became a lecturer in mission history at Lund University. A prolific, if perhaps not very original author, Lindeberg published a dozen monographs and several hundred articles on missionrelated subjects, all of them written in Swedish. Most of his publications were not intended for an academic audience, but a more general public. In this article, I shall therefore emphasize Lindeberg's role as an active popularizer of academic mission studies.
\end{abstract}

\section{LINDEBERG'S ROAD TO MISSION STUDIES}

Gustaf Lindeberg grew up in Göteborg in southwestern Sweden, where his father was a vicar. After a brief period of history studies at the university college in his hometown, in 1900 he moved to Lund where he pursued theological studies, intending to become 
a priest in the Evangelical Lutheran Church of Sweden, the state church. ${ }^{1}$ Before his arrival in Lund, Lindeberg did not show any particular interest in missions, which later would become his real passion in life. When he looked back on his student years much later in life, he recalled that his mission interest was aroused in 1902, when he listened to a lecture by a Norwegian missionary to Madagascar. The lecture obviously triggered something in the mind of young Lindeberg, who shortly thereafter started up a study group on Madagascar under the auspices of the Lund Students' Missionary Association, in which he became a very active member. ${ }^{2}$

Moving beyond the study of Madagascar, the members of the group read general works on mission, such as Gustav Warneck's textbook on Protestant mission history, Abriss einer Geschichte der protestantischen Missionen, which recently had appeared in a Swedish translation. ${ }^{3}$ Though not impressed by its scholarly standards, his acquaintance with Warneck's book caused Lindeberg to read many other books on mission history and theology. As an engaged member of the student missionary movement, Lindeberg took part in mission conferences in Scandinavia and Germany. At such occasions he met Professor Warneck, as well as other important figures in the missionary movement such as John Mott, Ruth Rouse and Japanese Bishop Honda. Later, Lindeberg emphasized the deep influence such personal meetings had had on him as a Christian and as a growing mission scholar. ${ }^{4}$

Having finished his bachelor of theology degree, Lindeberg wrote a licentiate dissertation in Church History. His newly awakened mission interest was, however, not reflected in his choice of subject; the dissertation was on the ecclesiology of Philipp Melanchton. ${ }^{5}$ In 1909, Lindeberg was ordained a priest in the Church of Sweden. Though he would never work as a regular parish priest, for fifteen years he served as a part-time chaplain at an infantry regiment close to Lund. Lindeberg would, however, primarily work as a teacher, first at a high school in Lund and later also at the university. ${ }^{6}$

Encouraged by Hjalmar Holmquist, the professor in Church History, Lindeberg continued his studies towards the doctoral degree. By then, he had indeed turned his academic interests to mission history. In 1918, when he was forty years old, he defended his doctoral thesis on the Protestant missions in Japan: Protestantismen $i$ Japan 1859-1913: historisk-principiell undersökning (Protestantism in Japan 1859-1913: A Historical and Systematic Investigation). The dissertation is a study of the work of the Protestant missionary societies in Japan from the opening of the country to foreign missionaries until World War I. Though Lindeberg had studied the sources for quite some time, the dissertation as such was written in a very short time, between

\footnotetext{
${ }^{1}$ Hallencreutz, 'Lindeberg, Gustaf Wilhelm'.

${ }^{2}$ Lindeberg, 'Missionsstudiets värde och betydelse'; Id., 'Studentmissionsföreningen i Lund'.

${ }^{3}$ Warneck, De protestantiska missionernas historia.

${ }^{4}$ Lindeberg, 'Missionsstudiets värde och betydelse'; see Id., 'Studentmissionsföreningen i Lund'.

${ }^{5}$ Data on Lindeberg's theological degrees are found in Lund University Library, Lund University Archives, Faculty of Theology, A I:8 and A I:9: Minutes 1902, 1904, and 1908. Lindeberg's handwritten licentiate dissertation from 1908 Studier rörande Melanchtons kyrkobegrepp (Studies on the Ecclesiology of Melanchton) is found in Lund University Library, Lund University Archives, Faculty of Theology, E 6A:99.

${ }^{6}$ Hallencreutz, 'Lindeberg, Gustaf Wilhelm'.
} 
May and September 1918. The book is based on writings by both Western and Japanese authors. Not knowing Japanese, however, Lindeberg had to rely on available translations into German, English and Scandinavian languages. In his dissertation, Lindeberg relates the Protestant missionary enterprise to the Japanese religions and what he sees as the Japanese national character.

\section{THE BIRTH, CHILDHOOD AND ADOLESCENCE OF MISSION STUDIES AT LUND}

Having successfully defended his thesis, Lindeberg became the first Swedish docent in mission history. This academic title could be loosely translated as associate professor, but did not automatically entail a teaching position. Instead it was rewarded to authors of dissertations that were considered particularly good. ${ }^{7}$

Nevertheless, mission studies was still not considered a separate discipline at Lund University. From 1903 onwards, the bachelor of theology degree was a requirement for ordination for priesthood in the Church of Sweden. Moreover, to be accepted as a student of theology, the candidates had to have completed basic university studies in Philosophy, History, Greek, Latin, and Hebrew. At the time, the bachelor of theology degree consisted of seven subjects: History of Religions, Old Testament Exegesis, New Testament Exegesis, Church History, Dogmatics, Theological Ethics, and Practical Theology. Having finished all their theoretical courses, those who were to become priests went to a pastoral seminar, where they were trained in preaching, teaching, and church law before ordination. ${ }^{8}$

Mission studies thus had no separate status in this scheme. A book on missions was part of the requirements for the licentiate degree in Practical Theology, but undergraduate students did not read a single text especially focused on mission. However, as early as 1912, at the General Missionary Conference in Stockholm, the delegates supported the foundation of a professorship in Mission Studies in either, or both, of the Swedish faculties. As is well known, a few such chairs had recently been founded in other places in the world and given the wide and growing interest in missions, it was argued that the subject ought to have a place within theological education in Sweden too. ${ }^{9}$

The Faculty of Theology at Lund University endorsed the suggestion made by the General Conference. At the same time, they proposed that Mission Studies should be made a separate, though optional, subject within the bachelor of theology degree. In 1912, and then again in 1918, members of Lund faculty wrote formal proposals in favour of the establishment of the chair. ${ }^{10}$ In 1912, having been offered a generous private donation, they even approached the Danish theologian and missionary to India Lars Peter Larsen, asking him whether he would be interested in a professor-

\footnotetext{
7 Lindeberg, 'En återblick, ett tack och ett farväl', 91.

${ }^{8}$ Persson, '1900-talet', 58.

${ }_{9}^{9}$ Myklebust, The Study of Missions in Theological Education, II, 145-160.

${ }^{10}$ Ibid., 145-150.
} 
ship. However, Larsen declined the offer, wanting to remain in India, and the project was not realized. ${ }^{11}$

As the faculty at Lund had too limited economic means to fund yet another full chair, it became clear that the planned professorship would have to be privately financed. In order to raise funds, in 1918 representatives of Church and Academia wrote an open letter to the 'church people' in southern Sweden. The letter was signed by the chancellor of Lund University, together with Archbishop Nathan Söderblom, six other bishops in the Church of Sweden, the dean of the Lund faculty and the chairman of the Lund Missionary Society. The proposed chair was seen as a way to assure a good education for future missionaries, but also as a means to emphasize the essential role of mission in church life. ${ }^{12}$

A separate chair in Mission Studies was needed, the faculty claimed, as the subject could not be satisfactorily integrated in either Church History or Practical Theology. In a report, the professor of Church History, Hjalmar Holmquist, argued at great length for the foundation of a separate chair:

Mission science is an historical discipline and mission has from the first days of Christianity been an important historical factor. ... The value of mission could of course be judged differently from different points of view. But nobody will deny the fact that mission has existed and continues to exist, now with even greater importance and with greater significance for mankind's spiritual life and general destiny. In such a case, historical research demands that also this aspect of human development becomes the object of scholarly endeavours. One might suppose, then, that the professor in church history would be responsible for such mission research. But as long as there is only one professor in church history, in either of our two faculties [Lund and Uppsala], who is responsible for both Swedish and general church history, there is practically no opportunity for him to also master the history of missions. Apart from this consideration, scientific research on missions demands knowledge, which hardly could be demanded of the church historian. Whereas he works with an area which belongs to the Christian cultural realm, the mission historian is brought to culturally and religiously very different worlds, which call for a special competence if the history of mission should be scientifically investigated ... Truly, mission history demands a representative of its own in the world of science. ${ }^{13}$

To the professor of Church History, it was clear that a Swedish church historian worked with the Christian West, whereas the mission historian worked with non-European church history and the history of Christian expansion in non-Christian parts of the world. Together with History of Religion, Mission Studies was thus seen as a kind of foreign office of the faculty, which called for insights in the history of other religions and non-European history. The term science of mission (missionsvetenskap), which

${ }^{11}$ On the faculty's contacts with L.P. Larsen, see Nielsen, 'L.P. Larsen and his Legacy'.

${ }^{12}$ The letter was circulated to all parishes in southern Sweden and was printed in Lunds Missions-

tidning 1918.

${ }^{13}$ Cited in Lindeberg, 'Missionshistoria som universitetsämne', 8-9 (my translation). 
now is used in Swedish, was seldom employed in these early documents, though Holmquist initially used the term in his letter. Instead terms such as missionshistoria (history of mission), missionskunskap (mission knowledge), or missionslära (doctrine of mission) were most often applied to the proposed subject. ${ }^{14}$

It was deemed that a capital of 200,000 Swedish crowns was necessary to cover the expenses of the chair. The fund-raising attempt was a partial success; after only a couple of months 80,000 crowns had been donated, which were given to Lund University on its 250th anniversary in September $1918 .{ }^{15}$ Though the fundraising initially had been quite successful, the Lund Missionary Society was not able to secure the necessary funds for a full professorship.

Nevertheless, in 1919 a part-time lectureship in Mission History was established at Lund. The lectureship was the first permanent teaching position in Mission Studies in any of the Scandinavian countries and Gustaf Lindeberg upheld it for more than twenty years until his retirement in 1943, but even after that he continued to teach the mission history course for yet another five years. During the first years of its existence, the lectureship was privately financed, but after a while the university agreed to pay the expenses. ${ }^{16}$

Although now considered a subject of its own, the course in mission history given by Lindeberg in the 1920s, 1930 s and 1940 s was not very substantial. In all, it consisted of fifteen to twenty hours of lectures every semester with complementary text seminars. It could thus not be compared to the traditional theological disciplines such as Biblical Studies or Dogmatics. ${ }^{17}$ It seems that every time the course was given, Lindeberg's lectures focused on a concrete geographical area or time period. The university catalogues mention Lindeberg as teaching about themes such as 'Indian church history' (1919), 'South African mission history' (1923), or 'Swedish nineteenthcentury missions' (1938), but also more unexpected ones such as Roman Catholic mission history (1927). For most of the time, Lindeberg's own textbook on Protestant mission history - Den Evangeliska Missionen (The Evangelic Mission) - was part of the required literature for the students.

During the first years, the course in mission history was an optional part of the bachelor of theology degree, but from 1930 onwards it was made obligatory. In 1947, when he had held his last lecture at the university, Lindeberg wrote an article about Mission History as an academic discipline. In the article, he argued that it was a real pity that 'such a substantial discipline' was not represented by a professor of its own. By then the Lund faculty once again suggested that there should be two professors in Church History: one of them should focus on Swedish and general church history and confession studies while the other should give special attention to mission history. For that reason, the faculty wanted to recruit a Swedish theologian who could teach, do research and uphold contact with the growing number of mission scholars in other parts of the world. The plans were not realized this time either. However, shortly

${ }^{14}$ On these and other terms, see Jongeneel, Philosophy, Science and Theology of Mission.

${ }^{15}$ Anshelm, 'Insamlingen för fonden till missionsprofessur i Lund', 10.

${ }^{16}$ Myklebust, The Study of Missions in Theological Education, II, 280.

${ }^{17}$ Ibid., 152. 
thereafter a full chair in 'church history, especially mission history' was established at Uppsala University with Bengt Sundkler as the first holder. ${ }^{18}$

For Lindeberg the core of the academic mission studies was the study of the expansion of Christianity among non-Christian people through the entire history of the Church, from the apostles onwards. Another important task was the study of the emerging independent churches on the non-European mission fields. In Lindeberg's vision, the mission historian should work in close cooperation with specialists on psychology and sociology of religion in order to analyse the process of conversion and the organization of missions and churches respectively. For both mission scholars and future missionaries, there was a great need to gain knowledge about the religions that Christian missionaries met on the field. Thus, to Lindeberg, a close cooperation between the disciplines of Mission Studies and History of Religion was absolutely necessary. ${ }^{19}$

In short, even at the end of Lindeberg's time as a lecturer, Mission Studies had a quite precarious position at Lund University. Despite great interest from the faculty and private donations, no chair was established and the course on missions remained minimal. Moreover, students were even required to obtain a special permit from the King in Council to write a licentiate's dissertation in Mission History, and until the late 1970 s the very few doctoral dissertations written on mission-related themes were written within the discipline of Church History. ${ }^{20}$ At Lund, a permanent chair in Mission Studies with Ecumenics had to wait until the early 1990s, though an adjunct part-time professor led a research seminar between 1979 and 1990, during which time a few doctoral dissertations were defended..$^{21}$ At Uppsala University, Mission Studies had a much more established status with a professor and an associate professor.

\section{LINDEBERG THE AUTHOR}

Though Lindeberg had a part-time teaching position at the university, for many years most of his daily work took place outside Academia. He taught Christianity at a high school in Lund and served as a priest. He was also a member of the town council representing the Conservative Party. Given these not very favourable conditions for academic work, the sheer volume of his literary production is quite outstanding. Apart from his dissertation, he wrote more than a ten books and hundreds of articles.

In the 1910 s and 1920s, Lindeberg wrote a number of monographs on the current missionary situation in the world with special reference to the Scandinavian Protestant missions. Among these monographs we find works such as: Hvad har den kristna världmissionen uträttat? (What has the Christian World Mission Accomplished?), 1918; Världsmissionens läge efter krigsåren (The Status of World Mission after the War), 1920; De svenska missionerna (The Swedish Missions), 1922, and Världsmis-

\footnotetext{
${ }^{18}$ Lindeberg, 'Missionshistoria som universitetsämne’.

19 Ibid.

${ }^{20}$ Myklebust, The Study of Missions in Theological Education, II, 152-154; see Lindeberg, Ett sekel $i$ missionens tjänst, 122-126.

${ }^{21}$ Lande and Lundberg, 'Missionsvetenskap med ekumenik'.
} 
sionens nutidsläge (The Current Status of World Mission), 1927. All these books were published by different organizations within the Church of Sweden and particularly deal with the relationship between mission and politics.

Lindeberg also published two textbooks that were re-edited a number of times: Den Evangeliska missionen (The Evangelic Mission), 1922; and Missionskunskap (Mission Knowledge), 1933. Both deal with the Protestant mission movement from the days of William Carey onwards, while focusing on the contemporary Christian mission. Another of Lindeberg's monographs which is worth mentioning in this context is his 1928 book on Roman Catholic mission, called Katolicismen i ljuset av dess missionsverksamhet (Catholicism in Light of its Missionary Activity), which could be considered a complement to his textbooks on the Protestant mission. The book is a quite sympathetic evaluation of Roman Catholic mission history and theory. One part of the work is devoted to mission history from the Middle Ages onwards, while the second is on contemporary mission theology, as presented in papal mission encyclicals.

In 1919, Lindeberg published a small book with the title Gudsordets gång genom världen och Bibeln på missionsfältet (The Ways of the Word of God through the World and the Bible on the Mission Field), in which he relates the history of Bible translation. He argues that the Bible is the book of mankind, due to the fact that God speaks to man through it, but that it becomes the book of mankind through the universal work of the Christian mission. Lindeberg thus argues for the central role of Bible translation in the missionary work.

Among his other books, Lindeberg wrote a monograph on the history of Lund Missionary Society: Ett sekel i missionens tjänst: Lunds missionssällskap 1845-1945 (A Century in the Service of Mission: Lund Missionary Society, 1845-1945), 1945 and a collection of biographical essays on Protestant missionaries called Märkesmän $i$ missionshistorien (Men of Distinction in the History of Missions), 1929.

Though Lindeberg wrote a dozen monographs, most of his literary publications had the form of articles. When in Lund, he became an active member of Lund Missionary Society, an independent confessional Lutheran missionary society founded in 1845. For most of its existence the society did not send any missionaries of its own, but instead contributed financially to the work of other missionary societies, in particular the German Leipzig Mission. ${ }^{22}$

In 1910, Lindeberg became the editor of the Society's monthly journal, a post he held for almost fifty years. Originally called Lunds Missionstidskrift (Lund Missionary Review), in 1921 the journal changed its name to Den evangeliska missionen (The Evangelic Mission). During his many years as the editor of the journal, Lindeberg would write most of its content: articles, summaries of public lectures, reviews of foreign and Nordic missionary literature, as well as summaries of the contents of foreign mission journals. ${ }^{23}$

The journal can hardly be called an academic publication. Its readership was above all priests and engaged lay people. However, with Lindeberg as the editor, the

${ }^{22}$ For a history of the Lund Missionary Society, see Lindeberg, Ett sekel i missionens tjänst. For a history of the early missionary societies in Sweden, see Sundkler, Svenska Missionssällskapet.

${ }^{23}$ Österlin, 'Gustaf Lindeberg och Den Evangeliska Missionen'. 
academic level of the contents improved. Given the journal's confessional standpoint, Protestant missions were given most attention, and in particular the regions in which Swedish missionaries were active, such as South Africa, China, Japan, India, Congo, and Ethiopia. Under headings such as 'From the mission field' and 'The general status of missions', for a long period Lindeberg published summaries of the Swedish and other missionary activities in various Swedish journals and yearbooks. ${ }^{24}$

\section{MISSION STUDIES FOR THE MASSES: POPULAR LECTURES}

Many of Gustaf Lindeberg's publications originated as lectures. He was above all a teacher and pedagogue. As has been indicated his texts were not primarily destined to academic theologians or other scholars. Instead, his main audience were students, priests, and 'mission friends', but also the general public. In late nineteenth-century and early twentieth-century Sweden vast numbers of adult education organizations and discussion clubs were founded. Another important feature of the time was the establishment of an extensive web of small lecture societies that were organized by political organizations, trade unions and religious groups.

At the beginning of the twentieth century, there was a wide-spread interest among Swedish academics to actively spread scholarly findings to the wider public, not least to counter-act the many lecturers who did have little formal education. The idea was often referred to as university extension and seen as a way to improve the knowledge of ordinary people. In the southern parts of Sweden, university extension was organized by a special department at Lund University. Founded in 1898, 'Centralbyrån för populära vetenskapliga föredrag' (the Central Bureau for Popular Science Lectures) provided the lecture societies in the area with lists of speakers and topics available. The main aim of the bureau was to present academic research in an accessible manner to people in small towns and on the countryside. By the 1930s, the Bureau helped to arrange between 1,000 and 1,500 lectures a year. ${ }^{25}$

Historian Johan Kärnfelt has studied the evolution of popular science and university extension in Sweden during the late nineteenth and early twentieth century. In his dissertation he points out that at the time there was a common belief that popular scientific books and popular lectures would contribute to the reform of the country. From a liberal or socialist perspective, adult education was seen as a presupposition for democracy. Kärnfelt writes:

When universal suffrage in Sweden was extended to all men in 1909 and to women in 1921, this task became even more pressing. It was widely argued that modern democracy did not only entail the right to vote. People also needed

\footnotetext{
${ }^{24}$ Such quite extensive summaries were published in Lunds Missionstidning (Lund Missionary Review) (1910-1920) and in its successor Den evengeliska missionen (The Evangelic Mission) (19211957), but also in Svensk Missionstidskrift (Swedish Missionary Review) (1914-1920) and Svenska Kyrkans Årsbok (Church of Sweden Yearbook) (1921-1951).

${ }^{25}$ Lindeberg, 'En återblick, ett tack och ett farväl', 90. For a comprehensive study on university extension in southern Sweden, see Sjövall, Centralbyrån i Lund för populära vetenskapliga föreläsningar and Poppius, När lundaprofessorerna höll populära vetenskapliga föreläsningar.
} 
education, knowledge and skills to enable them to participate actively in the political life. Elementary school teaching was far from sufficient to reach this aim and that is why the duty of the adult education movement and the authors of popular science became obvious during the first decades of the twentieth century. ${ }^{26}$

Some of these thoughts are present in Lindeberg's work as a popularizer of mission studies, though he in no way could be characterized as a liberal or radical, but decidedly conservative. Still, Lindeberg was a clear promoter of folkbildning. The term could be translated as informal adult education or perhaps popular education, though the concept often entails an important component of character building or spiritual formation (cf. German Bildung). The emphasis on folkbildning is implicit in many of Lindeberg's publications and on a number of occasions he refers explicitly to the concept. Already in 1915, he published an article on the relation between mission studies and folkbildning. There, he argued that Christian mission was one of the great popular movements in the contemporary era. Therefore the popularization of mission studies should be an integrated part of the folkbildning movement. In that context, he especially emphasized the importance of character building. In a quite traditional way he thought that the lives and works of 'great missionaries' and 'heroic native Christians' should serve as examples for ordinary people in Sweden. ${ }^{27}$

Lindeberg's version of folkbildning was in line with a reform conservative understanding of popular education. According to its representatives, the university should not be a closed world, and scholars should not only be devoted to research in the strict sense. The university teachers were seen as unquestionable authorities, and as such, they had a responsibility to contribute to the spiritual and intellectual formation of wider population groups. According Harald Hjärne, professor of History at Uppsala University, popularization would have positive effects for academicians as well. They should not only be 'examination machines' and 'monograph producers', but have a wider scope. When addressing a popular audience, they had to leave their work on scholarly details and deal with the 'big questions'. But university extension also had political implications. Hjärne meant that through popular lectures and publications, people from different social group could meet in order to overcome their narrow class interests. The ultimate goal of folkbildning should be harmony and unity in society. In the conservatives' view, popular education could thus be an efficient bulwark against radical socialism. ${ }^{28}$

Lindeberg returned to the topic of mission and folkbildning in a 1946 article on the importance and value of mission studies. He recalled his first lecture on mission in 1903 and stressed that ever since he had taught in many different contexts: school, university, church and lecture societies. In the article, he began with a reflection over the purpose of teaching. To him it was to let students and others 'reflect on life in its different modes'. Through good education, people should come in contact with the 'best that the people and humanity had to offer', that in his view was 'religiously

${ }^{26}$ Kärnfelt, Mellan nytta och nöje, 304.

${ }^{27}$ Lindeberg, 'Missionen och folkbildningen'.

${ }^{28}$ Kärnfelt, Mellan nytta och nöje, 219-228. 
and ethically important personalities'. Once again he returned to the idea of mission studies as a way to character building. In Lindeberg's view, those who attended his lectures and read his publications should be presented with examples of good, selfsacrificing persons who stood over personal gains. Such people could be both Western missionaries and indigenous Christians. According to Lindeberg they, not sport and movie stars, were real heroes who should be admired and emulated by young people. ${ }^{29}$

Based on his four-decade-long experience as a lecturer, he stressed that lectures on mission should not be presented in a form that differentiated them from lectures on other topics. The lecturer should refrain from using a 'sentimental and tearful voice', which according to Lindeberg was very common when speaking about missionary work. Instead, the lecturer should be 'vigorous and hearty', as well as 'concrete and lucid' in order to attract the attention of the audience and to communicate the message. Photographs and images too were important tools to make the lectures more attractive to the younger listeners. ${ }^{30}$ In Lindeberg's version of folkbildning, there was a clear component of missionary apologetics, though his lectures and books were not uncritical. In his view the popularization of mission studies had an important mission: to show people that Christianity was something living and dynamic, not a thing of the past. However, for Lindeberg the popularization of mission studies did not end with apologetics. According to him, the lecturer should also provide the audience with knowledge of 'foreign religions and cultures'. He asserted that an important feature of the popular lectures was to present an analysis of current religious, political and cultural developments in the so-called mission countries. The lectures should give the audience an up-to-date view of the world beyond Europe and North America, which was still quite unknown to most Swedes. ${ }^{31}$ It could very well be argued that this type of lectures had much in common with the ordinary talks given by missionaries who had returned from the mission fields. However, Lindeberg's lectures were not only destined to church-goers and 'mission friends'. He also taught in various 'secular' contexts, such as lecture societies.

\section{GUSTAF LINDEBERG: MISSION SCHOLAR AND POPULARIZER}

For Lindeberg, the study of mission was basically a historical discipline. Mission studies were basically equivalent with mission history, though he especially emphasized contemporary developments. In this way he resembled most of his Swedish colleagues within the field. However, unlike many of these people, he could not relate to longer or shorter periods on a foreign mission field or use source material found in these areas. Lindeberg was certainly no field researcher. He never had the possibility to visit any of the foreign mission fields on which he wrote so copiously. Nor did he work extensively with archival documents, except for brief stays in German and Brit-

\footnotetext{
${ }^{29}$ Lindeberg, 'Missionsstudiets värde och betydelse'.

${ }^{30}$ Ibid.

${ }^{31}$ Id., 'Missionen och folkbildningen'.
} 
ish archives when preparing his thesis. Instead, he can be looked upon as a competent compiler and synthesizer of missionary information, gained from the reading of a wide range of Nordic, English and German language monographs and periodicals.

Gustaf Lindeberg can hardly be described as an academic theologian. He was no missiologist. His main interest, as portrayed in his writings, was neither mission theology nor mission theory, but practical missionary work and particularly the relationship between politics and mission. He perceived the study of missions as an integrated, but specialised, part of church history, concerned with 'the expansion of Christianity among non-Christian peoples' and with 'the rupture between Christianity and the foreign religions'. However, he opposed the thought that Mission Studies was an auxiliary science or a mere exotic appendix to Church History, as he regarded mission as the very core of Christianity. On the other hand he stated that he would happily give up the thought of Mission History as a separate discipline, if church historians developed a more universal scope. Nevertheless, in the Swedish academic milieu, Church History was entirely focused on the Swedish, or at least Western European, context and nothing indicated that this would change in the near future. ${ }^{32}$

In conclusion, Gustaf Lindeberg was a prolific author in a period in which the Christian missionary movement went through important changes. He became the editor of Lund Missionary Review in 1910, the year of the Edinburgh World Missionary Conference, in the heyday of colonialism and missionary enthusiasm, and died in 1961, when the International Missionary Council merged with the World Council of Churches and colonialism in its traditional sense had begun to fade away. As a mission scholar, he was more interested in presenting updated syntheses to the greater public, than to deal with detailed research problems, and the role as a popularizer of mission studies seems to have suited him well.

${ }^{32}$ See in particular, Lindeberg, 'Missionsstudiets värde och betydelse'. 